\title{
Differential habitat use by demographic groups of the redfinger rubble crab Eriphia gonagra (Fabricius, 1781)
}

\author{
Andrade, LS. ${ }^{a *}$, Goés, JM. ${ }^{b}$, Fransozo, $V^{c}$, Alves, DFR. ${ }^{a}$, Teixeira, GM. ${ }^{d}$, and Fransozo, A. ${ }^{a}$

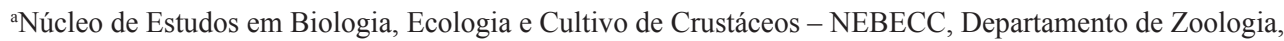 \\ Instituto de Biociências, Universidade Estadual Paulista - UNESP, Campus de Botucatu, Distrito de Rubião Junior, s/n, \\ CEP 18618-000, Botucatu, SP, Brazil

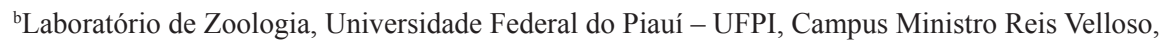 \\ Av. São Sebastião, 2819, Parnaíba, PI, Brazil \\ 'Departamento de Ciências Naturais, Universidade Estadual do Sudoeste da Bahia - UESB, Estrada do Bem Querer, \\ Km 04, CEP 45031-900, Vitória da Conquista, BA, Brazil \\ ${ }^{\mathrm{d}}$ Departamento de Biologia Animal e Vegetal, Universidade Estadual de Londrina - UEL, Rodovia Celso Garcia Cid, \\ PR 445 Km 380, Londrina, PR, Brazil \\ * e-mail: andradels.nebecc@gmail.com
}

Received: October 19, 2012 - Accepted: April 5, 2013 - Distributed: August 31, 2014

(With 4 figures)

\begin{abstract}
The structurally diverse rocky shores along the northern coast of the state of São Paulo, Brazil, support a varied fauna and provide refuges for many organisms. Some of these environments allow for extensive microhabitats, among them the sand reefs formed by the polychaete Phragmatopoma lapidosa, which occupy much of this area. The beauty of the landscape attracts large numbers of tourists, who contribute to the damage to the sand reef colonies, causing an imbalance in the patterns of population distribution and of this ecosystem. We describe the structure and population biology of the redfinger rubble crab Eriphia gonagra, and investigated the differential occupation of the habitat by each demographic category of this species. Crabs were sampled monthly for two consecutive years on the rocky coast of Grande Beach, Ubatuba, São Paulo, during spring low tides. Sampling was carried out over an area of approximately $1200 \mathrm{~m}^{2}$, during two hours on the rock surface and another two hours on the sand reefs. A total of 1407 crabs were collected; 776 on the sand reef (SR) and 631 on the rocky shore (RO). The majority of juvenile crabs inhabited the SR, while adult crabs were equally distributed in both microhabitats. This study showed that the SR is a natural nursery ground for the establishment of the early juvenile stages of E. gonagra, which use the reefs as a refuge and food resource. Many other organisms (mollusks, echinoderms, polychaetes etc.) settle on the reefs, and these areas may be among the most important in maintaining benthic diversity in the region.
\end{abstract}

Keywords: coastal structures, crab nursery, ecological zonation, Xanthoidea, ontogenetic habitat shift.

\section{Ocupação diferencial do habitat por grupos demográficos do caranguejo de dedos vermelhos Eriphia gonagra (Fabricius, 1781)}

\section{Resumo}

Os costões rochosos do litoral norte paulista, devido à sua constituição diversificada, sustentam uma grande diversidade de espécies animais e vegetais, além de proporcionar uma série de abrigos para proteção de muitos organismos. Em alguns destes costões ocorre a formação de microhabitats, entre eles os recifes de areia formadas pelo poliqueta Phragmatopoma lapidosa, que ocupam grande parte desta área. A paisagem diferenciada do local atrai um grande número de turistas, o que contribui para a deterioração das colônias que constituem esse recife, causando um desequilíbrio nos padrões de distribuição das populações desse ecossistema. Este trabalho visou levantar informações sobre a estrutura e dinâmica populacional de Eriphia gonagra, além de investigar uma ocupação diferencial do habitat por diferentes grupos etários deste caranguejo. Os caranguejos foram amostrados mensalmente, durante dois anos consecutivos, no costão rochoso da Praia Grande, Ubatuba, São Paulo, Brasil, em períodos de marés baixas de sizígia. A coleta ativa dos indivíduos foi efetuada em uma área de aproximadamente $1200 \mathrm{~m}^{2}$ por um período de duas horas na superfície rochosa e outras duas horas nos recifes de areia. Foi capturado um total de 1407 indivíduos, sendo 776 no recife de areia (SR) e 631 na superfície rochosa (RO). A maior parte dos jovens habita o recife, enquanto adultos encontram-se igualmente distribuídos nas duas áreas amostradas. Este estudo mostra que os recifes de areia podem ser considerados 
berçários de suma importância para o estabelecimento dos estágios juvenis de E. gonagra, que utilizam tais locais para proteção e alimentação. Muitos outros organismos (moluscos, equinodermos, poliquetas etc) se estabelecem sobre os recifes, sendo que essas áreas podem estar entre as mais importantes na manutenção da diversidade bêntica na região.

Palavras-chave: estrutura costeira, berçário de caranguejos, zonação ecológica, Xanthoidea, mudança de habitat na ontogênese.

\section{Introduction}

The benthic macrofauna comprises a diversity of aquatic animals that live closely associated with the bottom; they represent a fundamental link in the food chains of their respective ecosystems. They also act in processes that influence nutrient and contaminant cycling, such as bioaccumulation, trophic transfer, migration, biodegradation, and bioturbation (Reynoldson, 1987). Part of the benthic fauna live in intertidal zones and depend on this habitat to complete their life cycles; examples include the brachyurans Pachygrapsus transversus (Gibbes, 1850), Hexapanopeus schmitti Rathbun, 1930, and Menippe nodifrons Stimpson, 1859 (Flores and Negreiros-Fransozo, 1998; Mantelatto and Souza-Carey, 1998; Braga et al., 2005), and other invertebrates such as the isopod Ligia pallasii Brandt, 1833, shrimps and anemones, the anomuran Calcinus tibicen (Herbst, 1791), the mollusk Stramonita haemastoma (Linnaeus, 1758) among others, respectively studied by Carefoot (1973), Knowlton and Keller (1985), Fransozo and Mantelatto (1998) and Watanabe and Young (2006).

The rocky shore of Grande Beach (Ubatuba, state of São Paulo, Brazil) is composed of many large rocky outcrops and sand reefs, and this landscape attracts large numbers of tourists (Burone and Pires-Vanin, 2006). The sand reefs are a result of an accumulation of the polychaete worm Phragmatopoma lapidosa (Kinberg, 1867), and offer small structural refuges for infaunal organisms (Wilson, 1979). The rock surfaces also have concavities and crevices that can be used as shelter by larger animals than occupy the spaces available in P. lapidosa reefs.

Many decapod species and other marine invertebrates colonise marine habitats with spatially diverse structural features. Usually, juvenile individuals settle in a certain area, and subsequently migrate to other sites where food is more abundant and other essential factors for their growth and reproduction are more available. Occupation of specific sites as nursery grounds for the establishment and development of early post-larval stages is very common in brachyuran species; juvenile and adult crabs often occupy different habitats as they develop, because of their different needs for certain resources (Berrill, 1982; Fukui, 1988; Morgan and Christy, 1995; Flores and Negreiros Fransozo, 1998; Giménez et al., 2004).

The sand reefs produced by sabellariid polychaetes support several communities of decapod crustaceans (Coull and Bell, 1983). Almaça (1990) studied the crab community structure and interactions of these colonies, and noted the importance of the trophic relationship between polychaetes and crabs; the former are an important food resource for many species of the marine benthic and demersal fauna (Petti et al., 1996). Gore et al. (1978) found that $65 \%$ of the crustaceans associated with the sand reefs of Phragmatopoma caudata (Kröyer, 1856) in Florida (USA) utilise the sabellariids themselves as their main food resource. This kind of differential utilisation of food-habitat may be the key to the successful coexistence of diverse species in the same habitat. In addition, the sand banks of $P$. caudata constitute an important substratum for crustacean decapods, where megalopae of several species are intensively recruited, while juveniles and small adults share the substratum, searching for food and shelter from wave action (Bosa and Masunari, 2002).

Hall et al. (1991) stated that physical perturbations in benthic habitats influence the structure of marine communities, and in shallow coastal environments, the macrobenthic community is subject to a variety of changes. Soltan et al. (2001) observed that populations of the upper sublittoral on rocky shores and sand reefs are more affected than other shallow benthic populations, because they are more exposed to urban and industrial debris carried on the sea surface. According to Lopes et al. (1994), the northern coast of the state of São Paulo is particularly vulnerable to petroleum contamination, because of the intensive tanker traffic in the area. On rocky shores, the oil can remain adhered to the substratum, directly affecting the living organisms, especially larvae, preventing them from settling (Lopes et al. 1997). Experiments by Lopes et al. (1997) on rocky shores at São Sebastião in São Paulo demonstrated mortality of many individuals of Eriphia gonagra (Fabricius, 1781), among other invertebrates.

In addition to the vulnerability to petroleum contamination and the direct impacts of visitors, other human activities can have indirect effects on the intertidal flora and fauna. For example, shifts in the size structure of a population towards smaller and younger individuals may result in a disproportionate decrease in the reproductive ability of the population, because reproductive potential increases with size (Levitan, 1991). For species with long-lived pelagic larval stages, declines in reproductive output can affect both local and regional recruitment. Human activities can also result in cascading effects such as alteration of community processes through disruption of the ecological balance of competitors, predators, and/or food supply (Duran and Castilla, 1989), or through alterations in habitat conditions such as declines in the abundance of ecosystem engineers (Brown and Taylor, 1999; Schiel and Taylor, 1999). Studies on rocky-shore populations have provided useful data for future investigations concerning water quality (Fairweather, 1990) and human impact on coastal systems (Smith et al., 2008; Sanchez-Cabeza and Druffel, 2009). 
The redfinger rubble crab E. gonagra inhabits the intertidal zone of rocky shores, where it occurs in crevices and galleries formed by rock deposits, and also associated with sand reefs. According to Melo (1996), the distribution of E. gonagra is restricted to the western Atlantic, from North Carolina, USA, to Santa Catarina, Brazil. The goal of this study was to analyse the differential habitat occupation by different demographic groups of E. gonagra, in order to contribute to species preservation by increasing knowledge of its habitat use, from post-settlement to the adult and mature stages.

\section{Material and Methods}

\subsection{Field collections}

Crabs were sampled monthly, during spring low tides, from January 1996 through December 1997, on the rocky

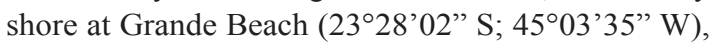
Ubatuba, São Paulo. Sampling was carried out by the same two collectors throughout the study period over the entire length of the rocky shore, including the sand reef and rocky portions, covering a total area of $1200 \mathrm{~m}^{2}$. Two sampling hours were dedicated to the rocky portion (RO) and another 2 hours to the sand reefs (SR) constructed by polychaetes (P. lapidosa).

\subsection{Laboratory procedure}

All crabs were packed in individual plastic bags to prevent agonistic behavior among specimens and consequent loss of appendages. In the laboratory, these were classified and grouped in demographic categories. Sex of specimens was determined from abdominal morphology (wide in females) and number of pleopods (2 pairs in males and 4 pairs in females). The adherence of the abdomen to the thoracic sternite and the gonad development stage were checked to distinguish adult from juvenile crabs (Guimarães and Negreiros-Fransozo, 2005). The number and size (maximum carapace width) of juvenile males (JM), adult males (AM), juvenile females (JF), adult nonovigerous females (AF), and ovigerous females (OF) were recorded, and the crabs were grouped in 12 size classes of $4 \mathrm{~mm}$ each, based on carapace width. A consignment of individuals collected in this study is integrated into a scientific collection of Study Group of Crustacean Biology, Bioscience Institute, of the Universidade Estadual Paulista Júlio Mesquita Filho.

\subsection{Statistical analyses}

The number of individuals was standardise per catch per unit effort (CPUE), i.e., crabs collected for $100 \mathrm{~m}^{2}$ ( 2 collectors $\mathrm{x} 2$ hours) in each month, as calculated by other researchers working on coastal monitoring (e.g. Kennelly, 1992; Seminoff et al., 2003; Adjers et al., 2006). All these data were tested for normality and homoscedasticity by the Shapiro-Wilk and Levene tests. The total abundance and the number of specimens of each demographic group were compared between the sampling areas (RO and SR) by Student's $t$ test. The sex-ratio in each area, and also for the total number of individuals was compared by means of a binomial test (Fisher 1930, Wilson and Hardy, 2002). The size of crabs was compared between RO and RS by the Mann-Whitney non-parametric test. All statistical analyses were performed according to Zar (1996), at the $5 \%$ significance level.

\section{Results}

A total of 1407 specimens were collected; 776 on the sand reef (SR) and 631 on the rocky portion (RO). The sex-ratio did not differ from the expected, except in 1997 at SR, when the number of females was higher ( $t$ test, $p<$ 0.01 ) (Table 1). The Mendelian ratio was observed in all size classes of males and females (Figure 1), except the $7^{\text {th }}$ (from 26 to $30 \mathrm{~mm}$ ), in which females predominated $(p=0.026)$.

Comparison of the abundance of each demographic group in each biotope revealed a strong predominance of juvenile crabs in SR (Table 2), whereas non-ovigerous adult females, ovigerous females, and adult males were distributed similarly between the two biotopes, in both sampling years. The mean size of the specimens collected in $\mathrm{SR}$ was $21.37 \pm 8.3 \mathrm{~mm} \mathrm{CW}$ (mean \pm standard deviation), and in RO was $25.15 \pm 8.7 \mathrm{~mm}$; these means differed statistically ( $t$ test; $T=8.3 ; p=0.00$ ). The mean size of each demographic group is shown in Table 3 . Taking into account the total number of males and females from each biotope (RO and SR), no significant differences between the sexes were observed. On the other hand, when the size of individuals was compared within the same demographic group, the largest individuals occurred in RO. The sizes of immature individuals obtained in SR and RO did not differ statistically.

Comparing the frequency of females by size class in each habitat showed that in SR, no females were captured in the

Table 1. Eriphia gonagra. Sex ratio and number of individuals on the sand reef (SR) and rocky surface (RO) from January 1996 to December 1997.

\begin{tabular}{|c|c|c|c|c|c|c|c|c|c|}
\hline \multirow{2}{*}{ Reef } & \multirow{2}{*}{ Year } & \multicolumn{3}{|c|}{ Females } & \multicolumn{2}{|c|}{ Males } & \multirow{2}{*}{ Total } & \multirow{2}{*}{$\begin{array}{c}\text { Sex ratio } \\
\mathrm{M}: \mathrm{F}\end{array}$} & \multirow{2}{*}{$\mathbf{P}$} \\
\hline & & AF & OF & TJ & AM & TJ & & & \\
\hline \multirow[t]{2}{*}{ Sand } & 1996 & 135 & 42 & 116 & 175 & 100 & 568 & 1.0:1.1 & $0.44_{\mathrm{ns}}$ \\
\hline & 1997 & 76 & 40 & 7 & 83 & 2 & 208 & $1.0: 1.4$ & $0.01 *$ \\
\hline \multirow[t]{2}{*}{ Rock } & 1996 & 83 & 41 & 11 & 103 & 6 & 244 & 1.0:1.2 & $0.10_{\mathrm{ns}}$ \\
\hline & 1997 & 101 & 53 & 36 & 154 & 43 & 387 & 1.0:1.0 & $0.70_{\mathrm{ns}}$ \\
\hline
\end{tabular}

*P<0.01; AF: Adult females. OF: Ovigerous females. AM: Adult males. TJ: Total Juveniles. 


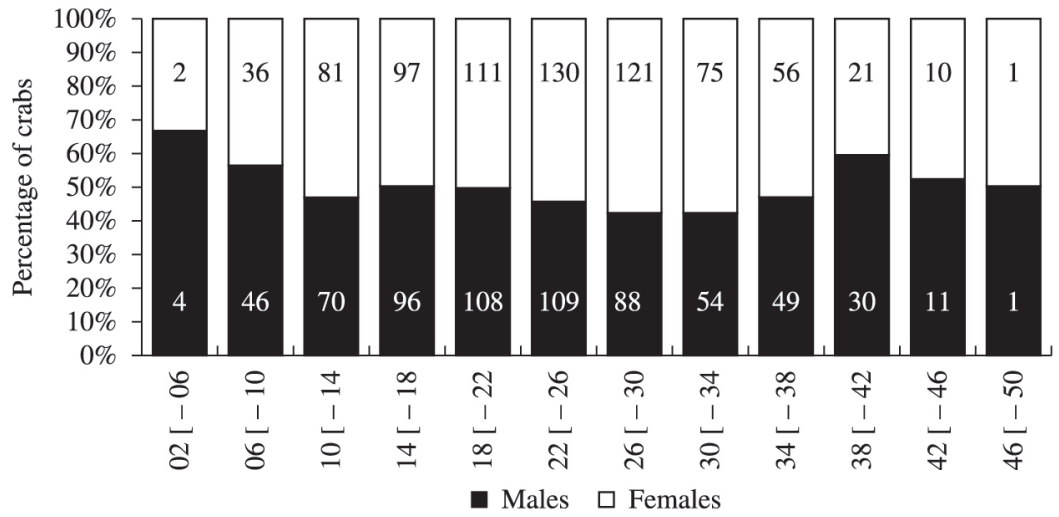

Figure 1. Percentages of males and females of Eriphia gonagra. Percentages of males and females per size class during the study period.

Table 2. Eriphia gonagra. Mean numbers of individuals and standard deviations (sd) of demographic groups on the sand reef (SR) and rocky surface (RO).

\begin{tabular}{llcccc}
\hline \multicolumn{1}{c}{ Local } & Year & AF & OF & AM & TJ \\
\hline Sand reef & 1996 & $11.3 \pm 5.3$ & $3.5 \pm 2.2$ & $14.6 \pm 6$ & $18 \pm 7.7$ \\
& 1997 & $6.3 \pm 2.6$ & $3.3 \pm 2.1$ & $6.9 \pm 2.6$ & $0.8 \pm 1$ \\
& Total & $8.8 \pm 4.8$ & $3.4 \pm 2.1$ & $10.8 \pm 6$ & $9.4 \pm 10.3$ \\
Rock reef & 1996 & $6.9 \pm 3.6$ & $3.4 \pm 2.2$ & $8.6 \pm 2.3$ & $1.4 \pm 1.1$ \\
& 1997 & $8.4 \pm 4.3$ & $4.4 \pm 1.8$ & $12.8 \pm 5.6$ & $6.6 \pm 5.9$ \\
& Total & $7.7 \pm 3.9$ & $3.9 \pm 2$ & $10.7 \pm 4.7$ & $4 \pm 4.9$ \\
\hline Sand $v$ s. Rock & 1996 & $\mathrm{~T}=2.35^{*}$ & $\mathrm{~T}=0.09$ & $\mathrm{~T}=3.23^{*}$ & $\mathrm{~T}=7.41^{*}$ \\
& 1997 & $\mathrm{~T}=1.45$ & $\mathrm{~T}=0.20$ & $\mathrm{~T}=3.31^{*}$ & $\mathrm{~T}=3.35^{*}$ \\
& Total & $\mathrm{T}=0.89$ & $\mathrm{~T}=1.15$ & $\mathrm{~T}=0.03$ & $\mathrm{~T}=2.30^{*}$ \\
\hline
\end{tabular}

T: value of $t$-test for independent samples. AF: Adult females. OF: Ovigerous females. AM: Adult males. TJ: Total juveniles; ${ }^{*} \mathrm{p}<0.01$.

Table 3. Eriphia gonagra Fabricius, 1781. Minimum, maximum, mean size and standard deviation (sd) of carapace width $(\mathrm{mm})$ in each demographic group from the sand reef and rock surface.

\begin{tabular}{|c|c|c|c|c|c|c|c|}
\hline \multicolumn{8}{|c|}{ CARAPACE WIDTH (mm) } \\
\hline \multirow{2}{*}{ AGE GROUP } & \multicolumn{3}{|c|}{ Sand reef } & \multicolumn{3}{|c|}{ Rock surface } & \multirow{2}{*}{$\begin{array}{l}\text { Sand vs } \\
\text { Rock (Z) }\end{array}$} \\
\hline & Min & Max & Mean \pm SD & Min & Max & Mean \pm SD & \\
\hline $\mathrm{JF}$ & 6.8 & 19.7 & $12.56 \pm 2.8$ & 4.7 & 17,9 & $12.29 \pm 3.6$ & -0.01 \\
\hline $\mathrm{JM}$ & 4.3 & 16.6 & $11.21 \pm 2.9$ & 5.8 & 15,9 & $11.48 \pm 2.7$ & -0.58 \\
\hline OF & 18.6 & 44.1 & $28.11 \pm 5.8$ & 17.7 & 43.0 & $30.08 \pm 5.7$ & $-2.34 *$ \\
\hline $\mathrm{AF}$ & 10.8 & 42.3 & $24.05 \pm 5.9$ & 13.3 & 46.1 & $26.84 \pm 7.0$ & $-3.83 *$ \\
\hline AM & 13.7 & 49.6 & $25.24 \pm 7.1$ & 13.9 & 45.1 & $27.09 \pm 7.4$ & $-2.99 *$ \\
\hline
\end{tabular}

Z: value of Mann-Whitney test. JF: juvenile females. JM: juvenile males. OF: Ovigerous females. AF: Adult females. AM: Adult males; *p $<0.01$.

first and final size classes. In this biotope, juvenile females reached $19.7 \mathrm{~mm} \mathrm{CW}$. In $\mathrm{RO}$, the largest immature female found was $17.9 \mathrm{~mm}$, and the largest mature female was 46.1 mm CW. Males (Figure 2), which were present from the first size classes in both locations, reached larger sizes in SR as both juveniles (16.6 mm) and adults (49.6 mm).

For each year (Figure 3), 1996 showed more juveniles in SR, whereas adult crabs predominated in 1997. In 1996, more adult crabs than juveniles were caught in RO; in 1997 , more juveniles were caught. The number of individuals/100 $\mathrm{m}^{2}$ (CPUE) per month revealed that non-ovigerous females were most abundant, in both biotopes, from January through July, and less abundant in late winter and early spring. Ovigerous females were more abundant in the latter period, although they were present year-round in both places, with estimated densities of $1.17 \pm 0.5$ and $1.0 \pm 0.5 / 100 \mathrm{~m}^{2}$ for SR and RO, respectively. Adult males were abundant during the entire study period. Juveniles were abundant year-round in SR, while in RO their numbers declined in autumn and early spring. The recruitment percentage in 

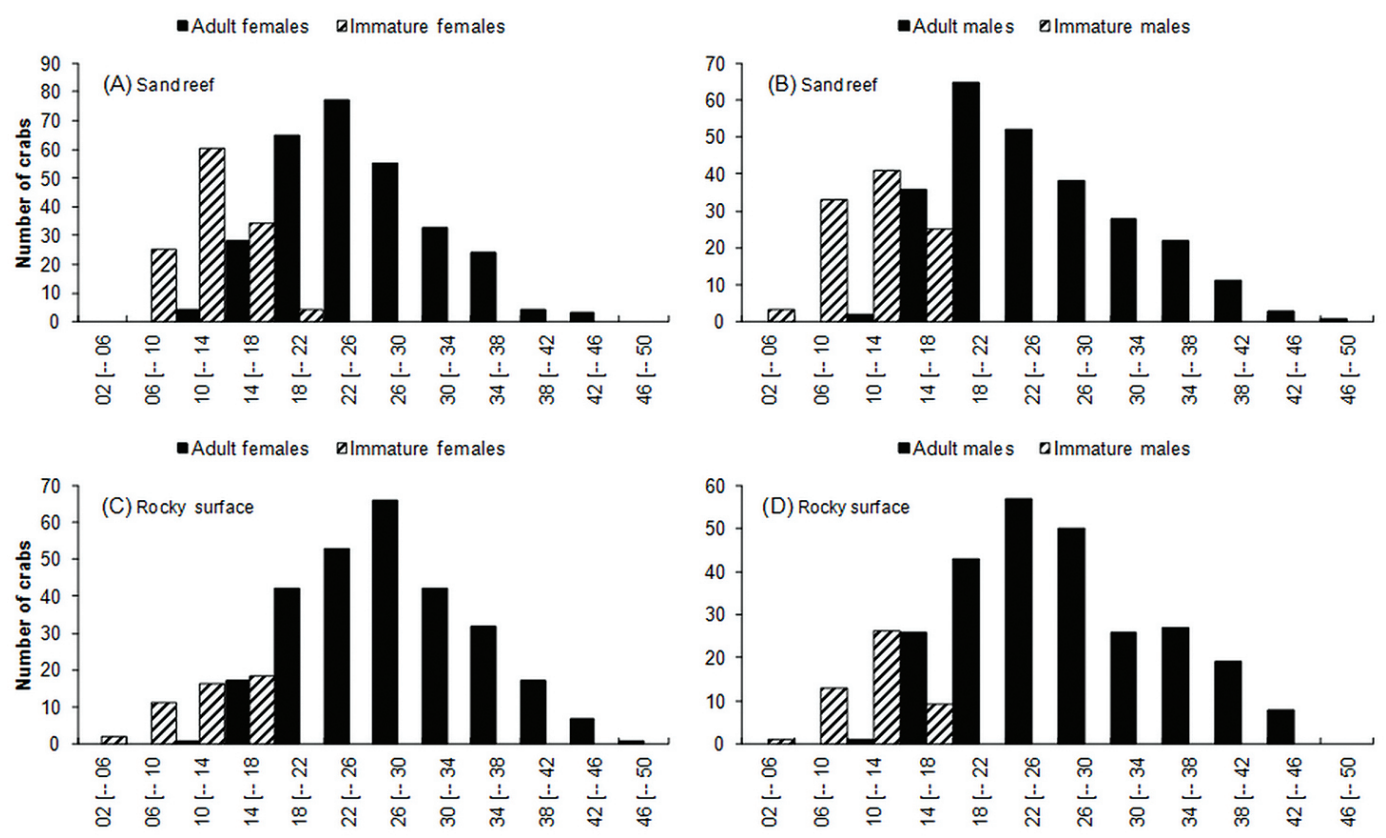

Figure 2. Absolute size-frequency distribution of Eriphia gonagra. Absolute size-frequency distribution of females (A, C) and males $(B, D)$ on the sand reef-SR $(A, B)$ and rocky surface-RO $(C, D)$.

the RO was inversely proportional to the number of adult mature females; whereas in SR, the percentages of recruits and adult mature females were similar (Figure 4).

\section{Discussion}

The size-frequency distribution of crabs was higher in SR than in RO, which could indicate that this habitat is more suitable for colonisation and establishment of the species, because of the greater availability of food (Burone and Pires-Vanin, 2006). According to Eckelbarger (1976), banks of Phragmatopoma lapidosa provide a relatively stable and suitable environment for the establishment of these populations, because after a disturbance caused by natural abrasion, human action or wave impact, the colonies develop rapidly and can re-establish themselves within a few days. The numerous crevices in the RO can protect E. gonagra against predation by fish and other, larger crabs, since they are widely used as a shelter. Also, the colouration of E. gonagra is very similar to the environment (algae-covered rocks), providing mimetism in these conditions.

In both RO and SR, the sex-ratios were close to the Mendelian ratio ( $p>0.05$ ), as also observed by Góes and Fransozo (2000) for the same specie, as well captured in Ubatuba. However, this pattern is not found for other Eriphioidea crab, that share the same habitat. Oshiro (1999) found that the sex-ratio of the rock crab Menippe nodifrons was consistently in favour of females, despite some seasonal variations. Studies of Epialtus brasiliensis Dana, 1852 and Acanthonyx scutiformis Dana, 1851, both from rocky shores in the Ubatuba region (respectively studied by Negreiros-Fransozo, Fransozo and Reigada, 1994; and Teixeira et al., 2009), reported differing sexratios. However, in the present study, females predominated in only one size class, whereas males were most abundant in the intermediate size classes. This can be explained because sexually mature males are more active and are more exposed by their behavior when searching for females for mating and also during mating (Wirtz and Diesel, 1983). This feature might considerably increase the susceptibility of E. gonagra to predation.

According to Giesel (1972), the sex-ratio can modulate the population size, affecting the reproductive potential. Díaz and Conde (1989) suggested that this regulatory condition can be seen in species with differential growth rates and/ or life expectancy for each sex. Similarly, Wenner (1972) mentioned that differential mortality between the sexes, as well as other factors, can lead to a difference in the cost of brood production in each sex, such as the differential growth rates or size differences between sexes during the period of brood care, altering the sex ratio (Darnell, 1962).

The differences in habitat use by demographic groups of E. gonagra were evidenced by the higher abundances at SR. The large number and variety of shelters inside the colonies of $P$. lapidosa make this microhabitat a good place for juveniles to complete their development and growth, because the effect of predation is markedly reduced (Heck and Hambrook, 1991; Flores and Negreiros-Fransozo, 1998). The advantage of shelter was also suggested by Spivak et al. (1994) to account for the extremely high density of juveniles of Cyrtograpsus angulatus (Dana, 1851) found in colonies of Ficopomatus enigmaticus (Fauvel, 1923). Bosa and Masunari (2002) recorded a 


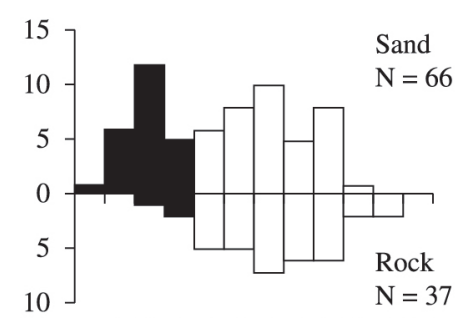

122345567889101112

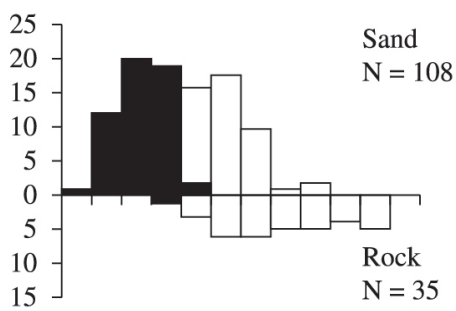

123345667899101112

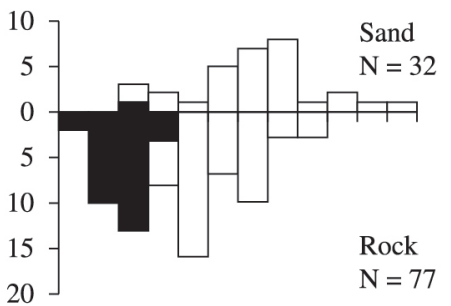

122345567889101112

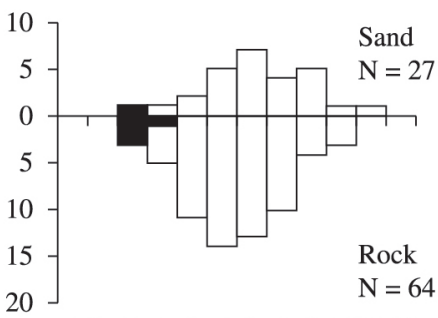

$\begin{array}{llllllllll}12 & 3 & 4 & 5 & 6 & 7 & 8 & 9 & 101112\end{array}$

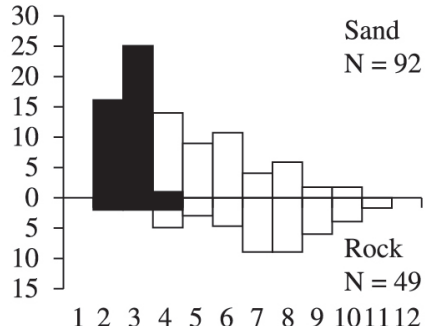

123345567889101112
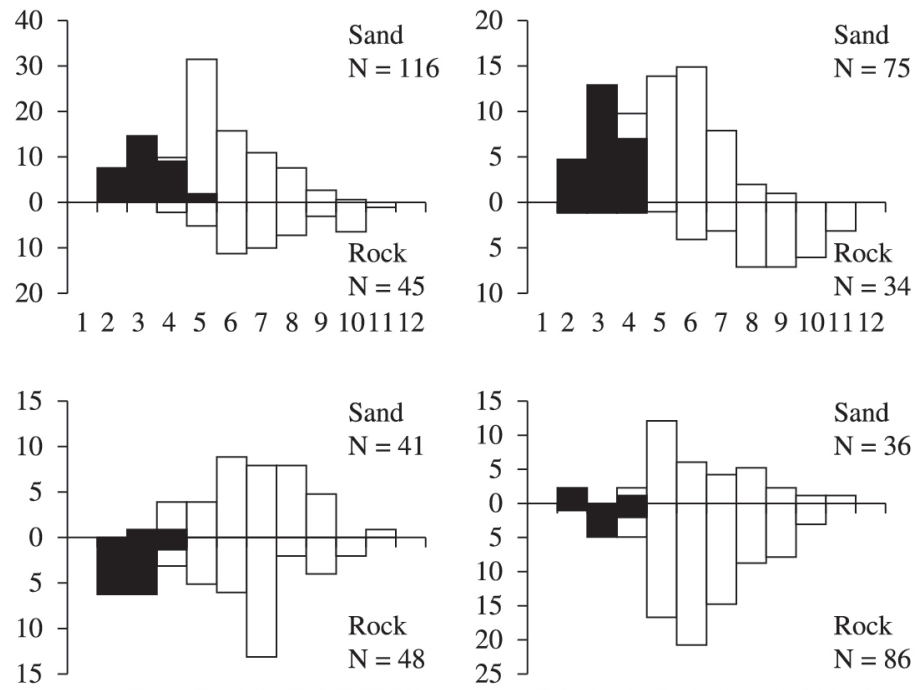

12234566789101112

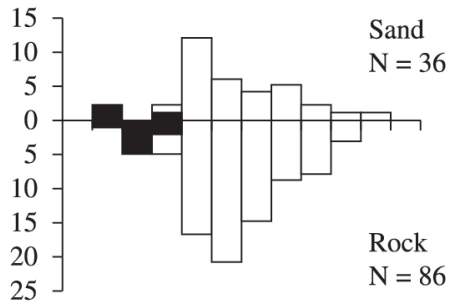

122345567889101112

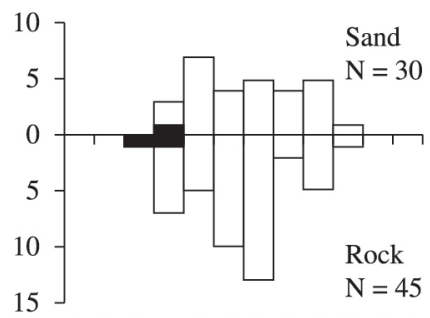

12344567789101112

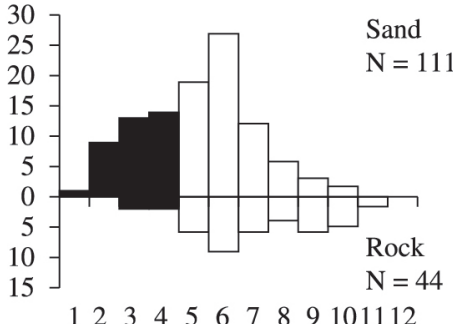

$\mathrm{N}=111$

$\begin{array}{llllllllll}1 & 2 & 3 & 4 & 5 & 6 & 7 & 8 & 9 & 101112\end{array}$

Figure 3. Size-frequency distribution of Eriphia gonagra. Bimonthly size-frequency distribution on the sand reef (SR) and rocky surface $(\mathrm{RO})$. $(\mathrm{N}=$ number of crabs; dark bars: juvenile crabs; white bars: adult crabs).

high percentage of juveniles of Petrolisthes armatus and Panopeus americanus associated with $P$. caudata at Caiobá Beach (Matinhos, state of Paraná, Brazil), compared with populations from rocky shores, which was related to the existence of appropriate microhabitats for the settlement of megalopae on sabellariid banks. Similarly, Logan Koch (1982) observed preferential recruitment of several species in locations with greater topographic complexity at the millimetre scale.

Although adult individuals were more abundant in RO, their numbers did not differ significantly from SR. When in very high abundance in SR, some adult and mature crabs probably migrate to RO for mating. This hypothesis seems plausible because mating occurs only after the puberty molt, when crabs are large enough and probably do not fit inside the small holes in the colonies. Factors such as this require habitat alteration in the transition from juvenile to adult. Similarly, Flores et al. (2002), studying the congeneric Eriphia verrucosa (Forskall, 1755) on a rocky coast of Portugal, noted that although it was the second most abundant species as adults, no juvenile crabs were found in the same place, which led the authors to suggest that juvenile and adult crabs select different substrates.

The size-frequency distribution of the demographic groups differed somewhat with reference to the two habitats and during the two years of the study. Juveniles were more numerous in SR than RO. The largest adult specimens tended to occupy the RO portion. This indicates that the SR portion is appropriate and important for juvenile recruitment, in which individuals find some needed resource 

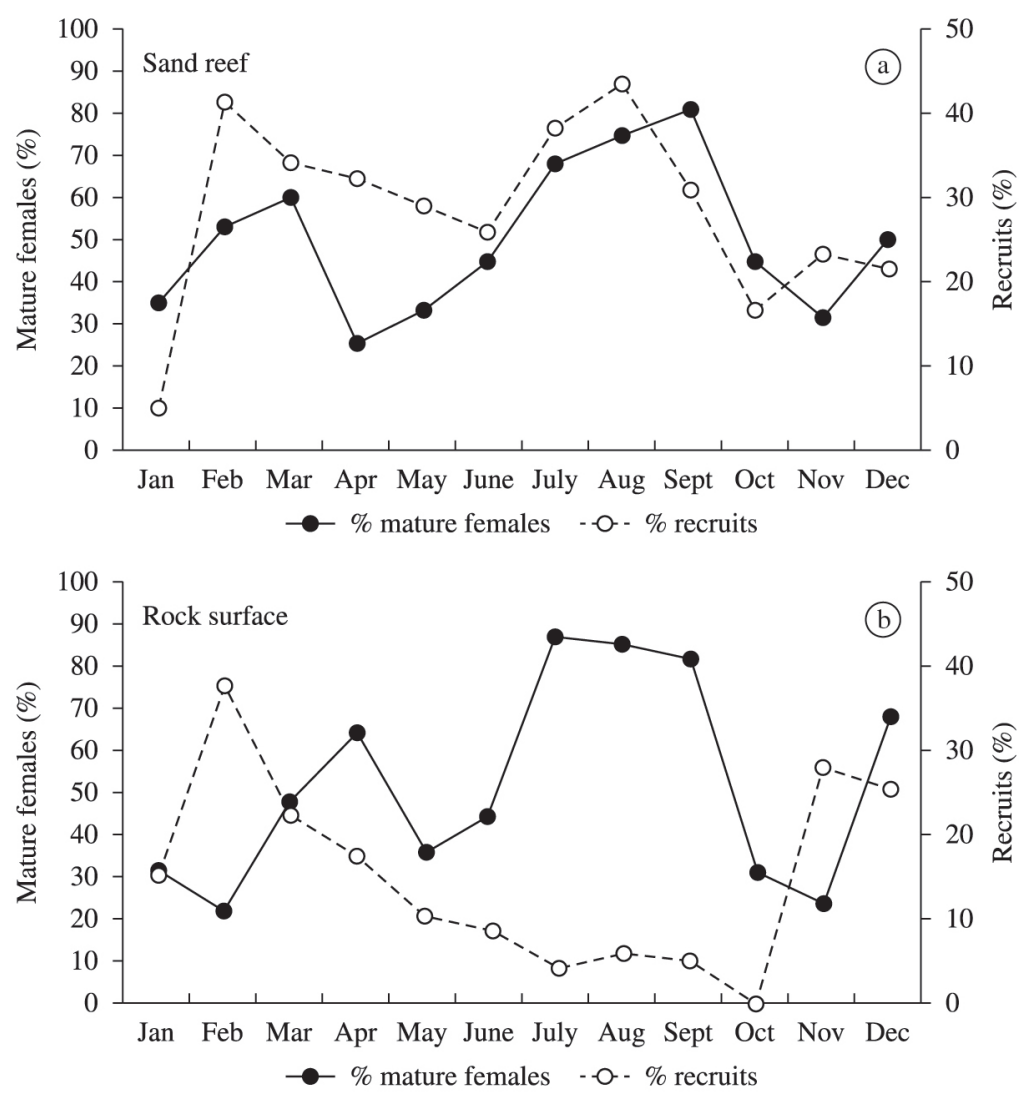

Figure 4. Recruits and mature females of Eriphia gonagra. Variation in the percentage of recruits and mature females on the sand reef-SR (a) and rocky surface-RO (b).

in abundance for this life-cycle phase; consequently, the availability of such microhabitats can be determinant for population density.

Johnson (1970) considered larval recruitment as one of the main factors responsible for the diversity of benthic communities. Recruitment success is dependent on both the morphology of the substratum and the existence of refuge sites (Shulman, 1984), which are widely found in P. lapidosa banks in SR. According to Anger (2006), several physical and chemical signals can effectively stimulate or prevent the establishment of brachyuran larvae, such as structural features of the bottom, salinity, light, water currents, water vibrations and odor, substratum, predators, foods, commensals, and adults of the same species.

Analysis of the seasonal distribution of E. gonagra revealed that the majority of juveniles colonise the sand reefs year-round, indicating continuous recruitment of the species and reinforcing the hypothesis of differential habitat preference according to crab size. The settlement of these juveniles on the sand reefs suggests the existence of a successful growth strategy, which may support the hypothesis of the stability of the population on the rocky shore, because juvenile crabs are fragile and vulnerable to predation, and the SR microhabitat contributes to this critical period of their life-cycle.
Many anomurans and brachyurans that inhabit the intertidal zone of the rocky shore and estuarine waters in temperate and tropical regions spawn over a prolonged period or continuously throughout the year (Sastry, 1983). Ovigerous females of E. gonagra were found year-round and with some peaks in their numbers, which indicates continuous reproduction and continuous recruitment, as is common for species in tropical and subtropical climates (Góes, 1995).

The present observations indicate that juveniles of E. gonagra remain in SR until they complete their juvenile development, and that some adults after the onset of sexual maturity, including many ovigerous females, are also found in this microhabitat. This could assure the production of offspring, although the largest crabs did not occur there, and also provide protection for small ovigerous females in their first spawning.

In the population of the grapsid crab $P$. transversus studied by Flores and Negreiros-Fransozo (1998) at the same location as the present study, some changes of habitat occurred with a considerable mortality rate, due to greater vulnerability and exposure to adverse environmental conditions. Adaptations to decrease the risk of predation during the changes in habitat could include more complex mechanisms, such as a colour change to provide a new 
mimetic pattern (Hines, 1982). This does not apply in the case of E. gonagra, which did not suffer a high mortality rate during the habitat change, and retains the same colour pattern throughout life.

As recommended by Oliva and Castilla (1986), studies of intertidal faunas should determine the magnitude of the populations, not only for target species subject to human exploitation, but also for other species that modulate the community equilibrium as a whole.

The SR areas are of great importance for the establishment and early growth of $E$. gonagra, because the species uses this microhabitat as a nursery ground. Additionally, during its life cycle, E. gonagra exploits at least two microhabitats, indicating effective adaptation to and stability in the intertidal rocky environment.

\section{Acknowledgements}

We are grateful to CAPES (Coordenação de Aperfeiçoamento de Pessoal de Nível Superior) for financial support. We also thank the NEBECC coworkers for their help during the fieldwork, and Dr. Janet Reid for her valuable help with the English language. All sampling in this study has been conducted in compliance with applicable state and federal laws.

\section{References}

ADJERS, K., APPELBERG, M., ESCHBAUM, R., LAPPALAINEN, A., MINDE, A., REPECKA, R. and THORESSON, G., 2006. Trends in coastal fish stocks of the Baltic Sea. Boreal Environmental Research, vol. 11, p. 13-25.

ALMAÇA, C., 1990. Structure and interactions in the crab community inhabiting Sabellariid worm colonies at Praia de Ribeira d'Ilhas (Ericeira, Portugal). Arquivos do Museu Bocage. Nova Série, vol. 1, no. 37, p. 505-519.

ANGER, K., 2006. Contributions of larval biology to crustacean research: a review. Invertebrate Reproduction \& Development, vol. 49, no. 3, p. 175-205. http://dx.doi.org/10.1080/07924259 .2006 .9652207 .

BERRILL, M., 1982. The life cycle of the green crab Carcinus maenas at the Northern end of its range. Journal of Crustacean Biology, vol. 2, no. 1, p. 31-39. http://dx.doi.org/10.2307/1548108.

BOSA, CR. and MASUNARI, S., 2002. Crustáceos decápodos associados aos bancos de Phragmatopoma caudata (Kröyer) (Polychaeta, Sabellariidae) na Praia de Caiobá, Matinhos, Paraná. Revista Brasileira de Zoologia, vol. 19, p. 117-133. http://dx.doi. org/10.1590/S0101-81752002000500006.

BRAGA, AA., FRANSOZO, A., BERTINI, G. and FUMIS, PB., 2005. Composição e abundância dos caranguejos (Decapoda, Brachyura) nas regiões de Ubatuba e Caraguatatuba, litoral norte paulista, Brasil. Biota Neotropica, vol. 5, no. 2, p. 45-78. http:// dx.doi.org/10.1590/S1676-06032005000300004.

BROWN, PJ. and TAYLOR, RB., 1999. Effects of trampling by humans on animals inhabiting coralline algal turf in the rocky intertidal. Journal of Experimental Marine Biology and Ecology, vol. 235, no. 1, p. 45-53. http://dx.doi.org/10.1016/ S0022-0981(98)00186-5.
BURONE, L. and PIRES-VANIN, AMS., 2006. Foraminiferal assemblages in the Ubatuba Bay, south-eastern Brazilian Coast. Scientia Marina, vol. 70, p. 203-217.

CAREFOOT, TH., 1973. Studies on the growth, reproduction, and life cycle of the supralittoral isopod Ligia pallasii. Marine Biology, vol. 18, p. 302-311.

COULL, BC. and BELL, SS., 1983. Biotic assemblages: populations and communities. In VERNBERG, FJ. and VERNBERG, WB. Behavior and Ecology. New York: Academic Press. p. 283-319.

DARNELL, RM., 1962. Sex ratios: Aquatic animals. In ALTMAN, PL. and DITTMNER, DS. Growth. Washington: Federation of American Societies for Experimental Biology. p. 439-442.

DÍAZ, H. and CONDE, JE., 1989. Populations dynamics and life history of the mangrove crab Aratus pisonii (Brachyura, Grapsidae) in a marine environment. Bulletin of Marine Science, vol. 45 , p. 148-163.

DURAN, LR. and CASTILLA, JC., 1989. Variation and persistence of the middle rocky intertidal community of central Chile with and without human harvesting. Marine Biology, vol. 103, no. 4, p. 555-562. http://dx.doi.org/10.1007/BF00399588.

ECKELBARGER, KE., 1976. Larval development and population aspects of the reef-building polychaete, Phragmatopoma lapidosa (Polychaeta, Sabellariidae). Bulletin of Marine Science, vol. 26, p. $117-132$

FAIRWEATHER, PG., 1990. Sewage and the biota on seashores: Assessment of impact in relation to natural variability. Environmental Monitoring and Assessment, vol. 14, no. 2-3, p. 197-210. http:// dx.doi.org/10.1007/BF00677916. PMid:24243323

FISHER, RA., 1930. The Genetical Theory of Natural Selection. Oxford, England: Clarendon Press. 272p.

FLORES, AAV. and NEGREIROS-FRANSOZO, ML., 1998. External factors determining seasonal breeding in a subtropical population of the shore crab Pachygrapsus transversus (Gibbes, 1850) (Brachyura, Grapsidae). Invertebrate Reproduction \& Development, vol. 34, no. 2-3, p. 149-155. http://dx.doi.org/10. 1080/07924259.1998.9652647.

FLORES, AAV., CRUZ, J. and PAULA, J., 2002. Temporal and spatial patterns of settlement of brachyuran crab megalopae at a rocky coast in Central Portugal. Marine Ecology Progress Series, vol. 229, p. 207-220. http://dx.doi.org/10.3354/meps229207.

FRANSOZO, A. and MANTELATTO, LFM., 1998. Population structure and reproductive period of the tropical hermit crab Calcinus tibicen (Decapoda: Diogenidae) in the region of Ubatuba, São Paulo, Brazil. Journal of Crustacean Biology, vol. 18, no. 4, p. 738-745. http://dx.doi.org/10.2307/1549150.

FUKUI, Y., 1988. Comparative studies on the life history of the grapsid crabs (Crustacea, Brachyura) inhabiting intertidal cobble and boulder shores. Publications of the Seto Marine Biological Laboratory, vol. 33, p. 121-162.

GIESEL, JT., 1972. Sex-ratio rate of evolution and environmental heterogeneity. American Naturalist, vol. 106, no. 949, p. 380-387. http://dx.doi.org/10.1086/282777.

GIMÉNEZ, L., ANGER, K. and TORRES, G., 2004. Linking life history traits in successive phases of a complex life cycle: effects of larval biomass on early juvenile development in an estuarine crab, Chasmagnathus granulata. Oikos, vol. 104, no. 3, p. 570-580. http://dx.doi.org/10.1111/j.0030-1299.2004.12957.x. 
GÓES, JM. and FRANSOZO, A., 2000. Sex ratio analyses in Eriphia gonagra (Crustacea, Decapoda, Xanthidae). Iheringia. Zoologia, vol. 88, p. 151-157.

GÓES, JM., 1995. Biologia populacional de Eriphia gonagra (Fabricius, 1781) (Crustacea, Decapoda, Xanthidae) na região de Ubatuba, SP. Botucatu: Universidade Estadual Paulista Júlio Mesquita Filho. 175 p. Dissertação de mestrado em Zoologia.

GORE, RH., SCOLTO, LE. and BECKER, LJ., 1978. Community composition, stability, and trophic partitioning in decapod crustaceans inhabiting some subtropical sabellariid worm reefs. Bulletin of Marine Science, vol. 28, p. 221-248.

GUIMARÃES, FJ. and NEGREIROS-FRANSOZO, ML., 2005. Juvenile development and growth patterns in the mud crab Eurytium limosum (Say, 1818) (Decapoda, Brachyura, Xanthidae) under laboratory conditions. Journal of Natural History, vol. 39, no. 23, p. 2145-2161. http://dx.doi.org/10.1080/00222930500061254.

HALL, SJ., BASFORD, DJ., ROBERTSON, MR., RAFFAELLI, DG. and TUCK, I., 1991. Patterns of recolonisation and the importance of pit-digging by the crab Cancer pagurus in a subtidal sand habitat. Marine Ecology Progress Series, vol. 72, p. 93-102. http://dx.doi.org/10.3354/meps072093.

HECK, KL. and HAMBROOK, JA., 1991. Intraspecific interactions and risk of predation for Dyspanopeus sayi (Decapoda: Xanthidae) living on polychaete (Filograna implexa, Serpulidae) colonies. Marine Ecology (Berlin), vol. 12, no. 3, p. 243-250. http://dx.doi. org/10.1111/j.1439-0485.1991.tb00256.x.

HINES, HA., 1982. Coexistence in a Kelp forest: size, population dynamics, and resource partitioning in a guild of spider crabs (Brachyura, Majidae). Ecological Monographs, vol. 52, no. 2, p. 179-198. http://dx.doi.org/10.2307/1942610.

JOHNSON, RG., 1970. Variations in diversity within benthic marine communities. American Naturalist, vol. 104, no. 937, p. 285-300. http://dx.doi.org/10.1086/282662.

KENNELLY, SJ., 1992. Distributions, abundances and current status of exploited populations of spanner crabs Ranina ranina off the east coast of Australia. Marine Ecology Progress Series, vol. 85, p. 227-235. http://dx.doi.org/10.3354/meps085227.

KNOWLTON, N. and KELLER, BD., 1985. Two more sibling species of alpheid shrimps associated with the Caribbean Sea anemones Bartholomea annulata and Heteractis lucida. Bulletin of Marine Science, vol. 37, p. 893-904.

LOGAN KOCH, RK., 1982. Patterns of abundance variation in reef fishes near an artificial reef at Guam. Environmental Biology of Fishes, vol. 7, no. 2, p. 121-136. http://dx.doi.org/10.1007/ BF00001782.

LEVITAN, DR., 1991. Influence of body size and population density on fertilization success and reproductive output in a freespawning invertebrate. The Biological Bulletin, vol. 181, no. 2, p. 261-268. http://dx.doi.org/10.2307/1542097.

LOPES, CF., MILANELLI, JC. and JOHNSCHER-FORNASARO, G., 1994. Programa de biomonitoramento de costões rochosos sujeitos a impactos por petróleo. In Simpósio sobre Ecossistemas da Costa Brasileira: Subsídios a um Gerenciamento Ambiental, 1994. São Paulo. São Paulo: Publicação ACIESP. p. 293-300. vol. 87.

LOPES, CF., MILANELLI, JC., PROSPERI, VA., ZANARDI, E. and TRUZZI, AC., 1997. Coastal Monitoring Program of São Sebastião Channel: Assessing the effects of 'Tebar V' Oil Spill on Rocky Shore Populations. Marine Pollution Bulletin, vol. 34, no. 11, p. 923-927. http://dx.doi.org/10.1016/S0025-326X(97)00079-9.
MANTELATTO, FLM. and SOUZA-CAREY, MM., 1998. Brachyura (Crustacea, Decapoda) associated to Schizoporella unicornis (Bryozoa, Gymnolaemata) in Ubatuba Bay (SP), Brazil. Brazilian Archives of Biology and Technology, vol. 41, p. 1-6.

MELO, GAS., 1996. Manual de Identificação dos Brachyura (Caranguejos e Siris) do Litoral Brasileiro. São Paulo: FAPESP. $604 \mathrm{p}$.

MORGAN, SG. and CHRISTY, JH., 1995. Adaptive significance of the timing of larval release by crabs. American Naturalist, vol. 145 , no. 3, p. 457-479. http://dx.doi.org/10.1086/285749.

NEGREIROS-FRANSOZO, ML., FRANSOZO, A. and REIGADA, ALD., 1994. Biologia populacional de Epialtus brasiliensis Dana, 1852 (Crustacea, Majidae). Revista Brasileira de Biologia, vol. 54, p. 173-180.

OLIVA, D. and CASTILLA, JC., 1986. The effect of human exclusion on the population structure of keyhole limpets Fisurella crassa and Fissurella limbata on the coast of central Chile. Marine Ecology (Berlin), vol. 7, no. 3, p. 201-217. http://dx.doi. org/10.1111/j.1439-0485.1986.tb00158.x.

OSHIRO, LMY., 1999. Aspectos reprodutivos do caranguejo guaia, Menippe nodifrons Stimpson (Crustacea, Decapoda, Xanthidae) da Baía de Sepetiba, Rio de Janeiro, Brasil. Revista Brasileira de Zoologia, vol. 16, no. 3, p. 827-834. http://dx.doi.org/10.1590/ S0101-81751999000300019.

PETTI, MA., NONATO, EF. and PAIVA, PC., 1996. Trophic relationships between polychaetes and brachyuran crabs on the southeastern Brazilian coast. Revista Brasileira de Oceanografia, vol. 44, no. 1, p. 61-67. http://dx.doi.org/10.1590/S141377391996000100007

REYNOLDSON, TB., 1987. Interactions between sediment contaminants and benthic organisms. Hydrobiologia, vol. 149, no. 1, p. 53-66. http://dx.doi.org/10.1007/BF00048646.

SANCHEZ-CABEZA, JA. and DRUFFEL, ER., 2009. Environmental records of anthropogenic impacts on coastal ecosystems: an introduction. Marine Pollution Bulletin, vol. 59, no. 4-7, p. 87-90. http://dx.doi.org/10.1016/j.marpolbul.2009.06.002. PMid:19560789

SASTRY, AN., 1983. Ecological aspects of reproduction. In VERNBERG, FJ. and VERNBERG, WB. The Biology of Crustacea. New York: Academic Press. p. 179-270.

SCHIEL, DR. and TAYLOR, DI., 1999. Effects of trampling on a rocky intertidal algal assemblage in southern New Zealand. Journal of Experimental Marine Biology and Ecology, vol. 235, no. 2, p. 213-235. http://dx.doi.org/10.1016/S0022-0981(98)00170-1.

SEMINOFF, JA., JONES, TT., RESENDIZ, A., NICHOLS, WJ. and CHALOUPKA, MY., 2003. Monitoring green turtles (Chelonia mydas) at a coastal foraging area in Baja California, Mexico: multiple indices to describe population status. Journal of the Marine Biological Association of the United Kingdom, vol. 83, no. 6, p. 1355-1362. http://dx.doi.org/10.1017/S0025315403008816.

SHULMAN, MJ., 1984. Resource limitation and recruitment patterns in a coral reef fish assemblage. Marine Biology and Ecology, vol. 74, no. 1, p. 85-109. http://dx.doi.org/10.1016/00220981(84)90039-X.

SMITH, JR., FONG, P. and AMBROSE, RF., 2008. The impacts of human visitation on mussel bed communities along the California coast: are regulatory marine reserves effective in protecting these communities? Environmental Management, vol. 41, no. 4, p. 599612. http://dx.doi.org/10.1007/s00267-007-9066-2. PMid:18185953 
SOLTAN, D., VERLAQUE, M., FRANÇOIS BOUDOURESQUE, C. and FRANCOUR, P., 2001. Changes in macroalgal communities in the vicinity of a Mediterranean sewage outfall after the setting up of a treatment plant. Marine Pollution Bulletin, vol. 42, no. 1, p. 59-70. http://dx.doi.org/10.1016/S0025-326X(00)00116-8. PMid:11382985

SPIVAK, E., ANGER, K., LUPPI, T., BASS, C. and ISMAEL, D., 1994. Distribution and habitat preferences of two grapsid crab species in Mar Chiquita Lagoon (Province of Buenos Aires, Argentina). Helgolaender Meeresuntersuchungen, vol. 48, no. 1, p. 59-78. http://dx.doi.org/10.1007/BF02366202.

TEIXEIRA, GM., FRANSOZO, V., COBO, VJ. and HIYODO, CM., 2009. Population features of the spider crab Acanthonyx scutiformis (Dana 1851) (Crustacea, Majoidea, Epialtidae) associated with rocky-shore algae from southeastern Brazil. Pan-American Journal of Aquatic Sciences, vol. 4, p. 87-95.

WATANABE, JT. and YOUNG, CM., 2006. Feeding habits and phenotypic changes in proboscis length in the southern oyster drill, Stramonita haemastoma (Gastropoda: Muricidae), on
Florida sabellariid worm reefs. Marine Biology, vol. 148, no. 5, p. 1021-1029. http://dx.doi.org/10.1007/s00227-005-0152-9.

WENNER, AM., 1972. Sex ratio as a function of size in marine Crustacea. American Naturalist, vol. 106, no. 949, p. 321-350. http://dx.doi.org/10.1086/282774.

WILSON, K. and HARDY, ICW., 2002. Statistical analysis of sex ratios: an introduction. In HARDY, ICW. Sex Ratios: Concepts and Research Methods. Cambridge: University Press. p. 48-92.

WILSON, WH., 1979. Community structure and species diversity of the sedimentary reefs constructed by Petaloproctus socialis (Polychaeta: Maldanidae). Marine Research, vol. 37, p. 623-641.

WIRTZ, P. and DIESEL, R., 1983. The social structure of Inachus phalangium, a spider crab associated with the sea anemone Anemonia sulcata. Zeitschrift für Tierpsychologie, vol. 62, no. 3, p. 209-234. http://dx.doi.org/10.1111/j.1439-0310.1983.tb02152.x.

ZAR, JH., 1996. Biostatistical Analysis. 3rd ed. New Jersey: Prentice-Hall. 718 p. 